\title{
Dynamic Organization of Emotions
}

\author{
Yumatov Evgeny* \\ Research Institute of Normal Physiology PK Anokhin, Russia
}

Submission: April 19, 2017; Published: April 24, 2017

*Corresponding author: EA Yumatov, PK Anokhin Research Institute of Normal Physiology, I. M. Sechenov First Moscow State Medical University, National Research University, Moscow Power Engineering Institute, Moscow, Russia, Email: eayumatov@mail.ru

\section{Introduction}

Emotions are one of the forms of mental activity of the brain, which has enormous biological, evolutionary and social significance. They are powerful incentives for the survival and satisfaction of human and animal social or biological needs [13]. Different views on the biological role and causes, negative and positive emotions are presented in the well-known theories of emotions [1-9].

"Biological theory of emotions" PK Anokhina [3] points out the key role of emotions in the organization of purposeful behavior and gives a general characterization of the development of emotions at the initial and final stages of the formation of behavior [3]. Without detracting from the importance of the fundamental systemic representations of PK Anokhin [3] about the organization of emotions, it can be noted that the "Biological Theory of Emotions" does not take into account all the factors and does not give a complete "picture" of the development of emotions at different stages of purposeful behavior.

According to the Information Theory of Emotions, PV Simonov [9], the degree of expression of emotion depends on the biological or social needs and the difference between the necessary information, and that which the individual really owns to achieve the goal $[8,9]$. "Information theory of emotions" focuses on the causes of the emergence of emotions at the stage of the emergence of the need and does not disclose the entire dynamics of emotions in the process of implementing a purposeful behavioral act.

Thus, none of the described theories of emotions provides a complete picture of the formation of emotions in the dynamics of repeatedly repeated purposeful behavior with successful or unsuccessful results. Based on the ideas about the formation of emotions in the Biological Theory of Emotions and the Information Theory of Emotions, we developed the Dynamic Theory of Emotions, which characterizes the progressive development of positive, negative emotions at different stages of purposeful behavior, taking into account the changing relationships between predicted probability and real Achievement of the result, individual characterological traits of the individual $[10,11]$

"Dynamic theory of emotions" comprehensively describes the development of different emotions in the dynamics of purposeful behavior and, in particular, the emergence of positive emotions in anticipation of the future result, the complete absence of emotions in the automated behavioral act, the desire for risky behavior with a low probability of achieving a result, with pronounced negative emotions. In the systemic organization of purposeful behavior, there is a relationship between negative and positive emotions. Without negative emotions, there are no positive emotions. The ratio of negative and positive emotions changes in the process of forming a successful, purposeful activity as it improves.

The main provisions of the "Dynamic Theory of Emotions" are confirmed by us in the complex analysis of the psycho physiological state of students [11]. Educational activity is a real model of behavior that reflects the general biological patterns of development of emotions and emotional tension. A multidimensional study of the individual group psycho physiological reactions of students in the educational and examination situation revealed the dependence of the development of emotions on the character traits of the personality, predicting the likelihood of achieving a result when comparing the expected and actually obtained examination score [11].

The psychophysiological state of students in a real exam situation convincingly demonstrated the validity of the "Dynamic Theory of Emotions", which encompasses the entire set of factors of the formation of emotions at different stages of purposeful behavior: the motivational state, probabilistic forecasting and actually achieved result, individual characterological personality traits. "Dynamic theory of emotions" most fully reveals the origin, biological role and participation of emotions in purposeful behavior. The basic principles of development of 
emotions, set forth in the "Dynamic Theory of Emotions," are universal in relation to various types of purposeful activity [11].

16-06-00810 RSFH on "Psycho physiological research of the correlation of emotional stress and the structure of the natural nighttime sleep among students with varying academic performance".

\section{References}

1. Darwin Ch (1896) Expression of spiritual unrest. St. Petersburg, Russia.

2. Darwin Ch (2001) On the expression of emotions in humans and animals. St. Petersburg, Peter, Russia.

3. Anokhin PK (1968) Biology and Neurophysiology of the conditioned reflex. M. Medicine, Russia, pp. 548.
4. James W (1884) What is emotion? Mind 9(34): 188-205.

5. Lange S (1895) Les emotions. Paris, Alcan, UK.

6. Cannon WB (1927) The James-Lange theory of emotions: a critical examination and an alternative theory. Am J Psychol 39: 106-124.

7. Izard K (2000) Psychology of emotions. St. Petersburg, Peter, Russia.

8. Simonov PV (1981) The emotional brain. M. Science, Russia.

9. Simonov PV (1987) Motivated brain. M. Science, Russia.

10. Yumatov EA (2009) Dynamic organization of emotions and emotional stress. Proceedings of the $6^{\text {th }}$ Simon Readings, Russia, pp. 13-46.

11. Yumatov EA, Glazachev OS, Bikova EV, Dudnik EN, Potapova OV, et al. (2017) Psychophysiology of emotions and emotional stress of the students. M. ITRK, Russia, pp. 200.

\section{Your next submission with JuniperPublishers will reach you the below assets}

- Quality Editorial service

- Swift Peer Review

- Reprints availability

- E-prints Service

- Manuscript Podcast for convenient understanding

- Global attainment for your research

- Manuscript accessibility in different formats

( Pdf, E-pub, Full Text, Audio)

- Unceasing customer service

Track the below URL for one-step submission https://juniperpublishers.com/online-submission.php 